Original Research Paper

\title{
The Resistance Evaluation of Dry Subtropics Brown Soils to Heavy Metal and Oil Contamination by Biological Indicators
}

\author{
Sergey Ilyich Kolesnikov, Natalya Aleksandrovna Petrova, \\ Kamil Shagidullovich Kazeev, Natalya Aleksandrovna Vernigorova, \\ Tatyana Mikhaelovna Minkina, Svetlana Nikolaevna Sushkova and Yuliya Viktorovna Akimenko \\ Southern Federal University, Academy of Biology and Biotechnology, \\ 344090, Russia, Rostov-on-Don, Stachkiave., 194/1, Russia
}

\author{
Article history \\ Received: 04-12-2014 \\ Revised: 02-08-2016 \\ Accepted: 04-08-2016 \\ Corresponding Author: \\ Sergey Ilyich Kolesnikov \\ Southern Federal University, \\ Academy of Biology and \\ Biotechnology, 344090, \\ Russia, Rostov-on-Don, \\ Stachkiave., 194/1, Russia \\ Email: kolesnikov@sfedu.ru
}

\begin{abstract}
Contamination of brown calcareous soils with $\mathrm{Cr}, \mathrm{Cu}, \mathrm{Ni}, \mathrm{Pb}$ and oil leads to deterioration of their biological properties. There is a reduction in activity of catalase and dehydrogenase, an abundance of Azotobacter genus bacteria, cellulolytic activity and the length of radish roots. As a rule, there is a direct relationship between the content of contaminant in the soil and degree of deterioration of biological properties of the soil. According to the degree of negative impact on the biological properties of brown soil heavy metals form the following series: $\mathrm{Cr}>\mathrm{Cu}>=\mathrm{Pb}>=\mathrm{Ni}$. The pattern that chromium is more toxic and copper, lead and nickel have less and similar to each other degree of toxicity was established earlier in research conducted by the same method, with other soils in southern Russia. According to the degree of resistance brown soils are close to chestnut soils, they are less stable than chernozems and more stable than brown semi desert soils. Regional standards of $\mathrm{Cr}, \mathrm{Cu}, \mathrm{Ni}, \mathrm{Pb}$ and oil content in brown soils of Ciscaucasia dry subtropics Ciscaucasia are proposed.
\end{abstract}

Keywords: North Caucasus, Brown Soil, Resistance, Contamination, Heavy Metals, Oil

\section{Introduction}

Brown soils-dry subtropics soils-are widespread in southern Europe, North Africa, in the countries of the Near East, in China, in the west of the United States, in the central part of Chile and southern Australia. For Russia, brown soils are unique, requiring special protection. In Russia, they are found only in the North Caucasus (Krasnodar region, Dagestan, Chechnya) and in the Crimea (Valkov et al., 2008; Kazeev et al., 2010). Currently, economic and recreational development of these regions leads to increased anthropogenic impact, including chemical contamination, on soil.

In this regard due to the rarity, little use in agriculture and remoteness from major pollution sources brown soils remain unexplored in terms of resistance to chemical contamination so far. There are two approaches to the standardization of environmental quality. On the one hand, it is possible to standardize the content of contaminating substances in environment objects, on the other hand there is a degree of environment transformation caused by pollution. Each of these approaches or a combination of both should be efficiently used in different cases (Matveev et al., 2001; Gebrekidan et al., 2013; Chakraborty et al., 2014).

The purpose of this paper is to assess the resistance of brown soils to contamination with heavy metals $(\mathrm{Cr}$, $\mathrm{Cu}, \mathrm{Ni}, \mathrm{Pb}$ ) and oil by biological indicators (in a model experiment).

\section{Materials and Methods}

To achieve the purpose a number of model experiments were carried out. Brown calcareous soil was used as the object of research (Table 1) (Krasnodar region, Labinskiy district).

The soil from the layer of $0-25 \mathrm{~cm}$ was used. It is the layer which accumulates major quantity of substances polluting the soil. 
Table 1. Ecological-genetic and ecological-biological characteristics of the studied soil

\begin{tabular}{|c|c|c|c|c|c|}
\hline $\begin{array}{l}\text { Humus } \\
\text { content, \% }\end{array}$ & $\mathrm{pH}$ & $\begin{array}{l}\text { Grain } \\
\text { composition }\end{array}$ & $\begin{array}{l}\text { Catalase activity, } \\
\mathrm{ml}_{2} / \text { gr of soil } \\
\text { per } 1 \text { min }\end{array}$ & $\begin{array}{l}\text { Dehydrogenase } \\
\text { activity, mg TFF/10 gr } \\
\text { of soil in } 24 \mathrm{~h}\end{array}$ & $\begin{array}{l}\text { The abundance of } \\
\text { Azotobacter genus } \\
\text { bacteria \% lumps fouling }\end{array}$ \\
\hline $1,2 \%$ & 8,2 & Heavy loamy & 6,6 & 16,9 & 100 \\
\hline
\end{tabular}

Heavy Metals (HM) and oil were selected as contaminants. $\mathrm{Cr}, \mathrm{Cu}, \mathrm{Ni}$ and $\mathrm{Pb}$ were studied as contaminating HM, since the soil in southern Russia is largely contaminated by them (Dyachenko, 2004; Sheudzhen, 2003). In addition, the chosen HM are interesting for comparison, as their MPC is 100 $\mathrm{mg} \mathrm{kg}^{-1}$ of soil. MPC values developed in Germany were used in the research (Kasyanenko, 1992). Firstly, this is due to the fact that there is no MPC of total (gross) copper and nickel content in soil in Russia. Secondly, the "Russian" MPC of lead often cannot be used because there is too little content of this element in many soils.

There is also no developed MPC of oil in soil, so its content in the soil was expressed in per cent.

The impact of different amounts of soil pollutants was studied: HM-1, 10, 100 MPC (100, 1000 and 10000 $\mathrm{mg} \mathrm{kg}^{-1}$, respectively), oil $-1,5,10 \%$ of the soil weight

$\mathrm{HM}$ were introduced into the soil in the form of oxides: $\mathrm{CrO}_{3}, \mathrm{CuO}, \mathrm{NiO}, \mathrm{PbO}$. Firstly, a significant proportion of $\mathrm{HM}$ enters the soil in the form of oxides (Kabata-Pendias and Pendias, 1989). Secondly, the use of HM oxides eliminates the effects of associated anions on the soil properties, as it happens when metal salts are introduced.

Soil in pots was incubated at room temperature (20$\left.22^{\circ} \mathrm{C}\right)$ and optimum humidity $(60 \%$ of field waterholding capacity) in triplicate.

Soil conditions were determined 30 days after contamination. In assessing the chemical impact on the soil this period is the most informative (Kolesnikov et al., 2006).

Laboratory and analytical studies were performed using standard methods (MSU, 1991; Kazeev and Kolesnikov, 2012). The abundance of Azotobacter genus bacteria, the activity of catalase and dehydrogenase, celluloselytic activity, phytotoxic properties of soils and other indicators were determined. Azotobacter was calculated by lumps fouling method in Ashby medium. Celluloselytic ability was determined by the degree of cotton fabrics decomposition, exposed in the soil for 30 days. Catalase activity was measured according to Galstyan method, dehydrogenase-Galstyan procedure in Khaziyev modification. Phytotoxicity of the soil was determined by the length of radish roots.

On the basis of the most informative biological parameters the Integral Parameter of Biological State
(IPBS) of soil was measured (Kolesnikov et al., 2006). It was designed according to the following indicators: The abundance of Azotobacter genus bacteria, the activity of catalase and dehydrogenase, celluloselytic activity, the length of the roots of radish (phytotoxicity). Azotobacter genus bacteria are traditionally and successfully used as an indicator of the soil chemical contamination. Catalase, dehydrogenase and cellulolytic activity indicate the intensity of various biological processes in the soil. In this case, the enzyme activity is an indicator of potential biological activity of the soil and leaf decomposition rate characterizes the current activity. Catalase and dehydrogenase belong to the redox enzymes-the most sensitive to chemical contamination. The length of radish roots reflects the phytotoxic properties of chemically contaminated soil. The present set of indicators provides an informative picture of biological processes occurring in the soil and its ecological condition.

To calculate the value of IPBS each of the five above-mentioned controlled indicators (in the noncontaminated soil) was taken as $100 \%$ and in relation to it a percentage value is expressed in the other versions of the experiment (in the contaminated soil). Thereafter, the mean value of five chosen indicators was determined for each variant of the experiment. The methodology used allows integrating relative values of different indicators, the absolute values of which cannot be combined into a single indicator, since they have different units of measurement.

\section{Results and Discussion}

The study revealed that the contamination of brown soil with $\mathrm{Cr}, \mathrm{Cu}, \mathrm{Ni}, \mathrm{Pb}$, oil leads to its condition degradation. As a rule, there was a significant decrease in the studied biological indicators: Catalase (Fig. 1A) and dehydrogenase (Fig. 1B) activity, cellulolytic activity (Fig. 1C), the abundance of Azotobacter genus bacteria (Fig. 1D), the length of the radish roots (Fig. 1E) and Integral Parameter of Biological State (IPBS) (Fig. 1F).

Since the MPC of all four investigated HM is equal $\left(100 \mathrm{mg} \mathrm{kg}^{-1}\right)$, it is possible to compare their toxic effect in relation to the studied biological indicators. The results indicate that chrome had the most significant negative impact. Copper, lead and nickel showed less intensive effect. 


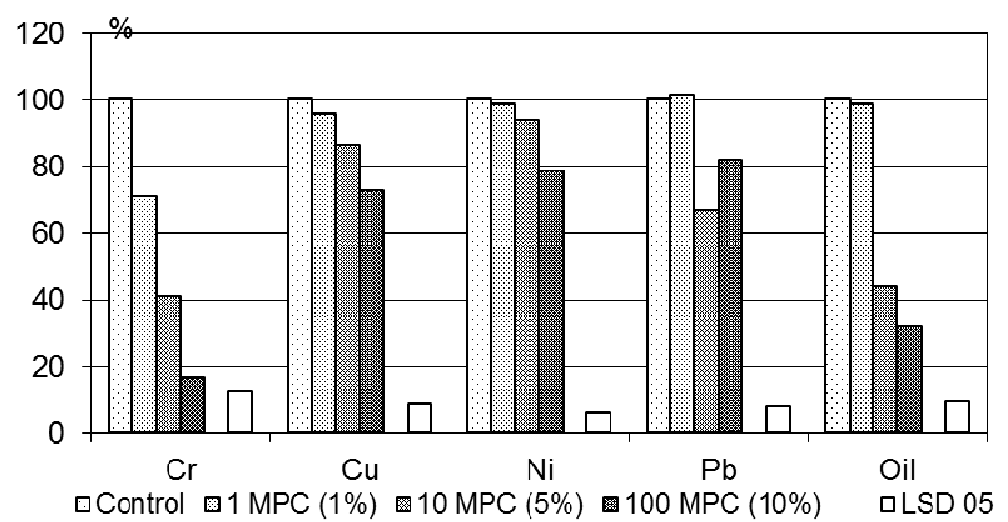

(A)

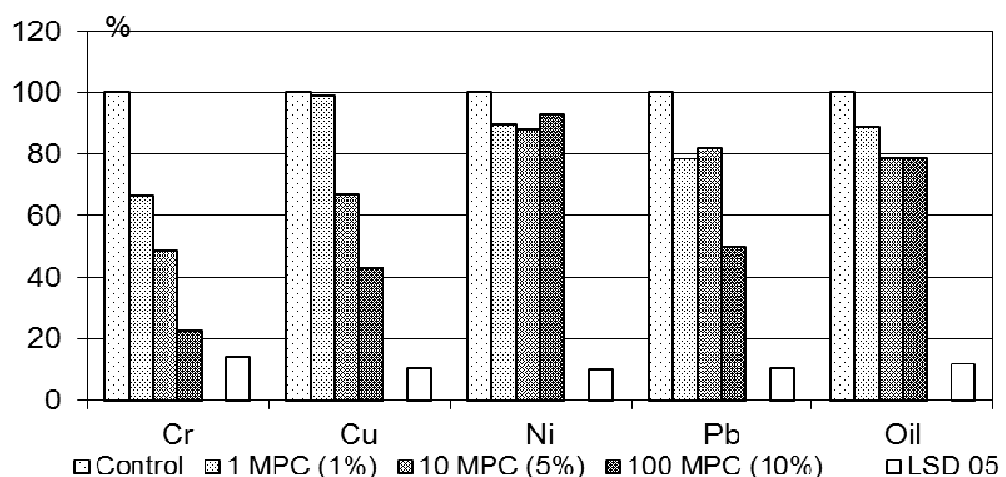

(B)

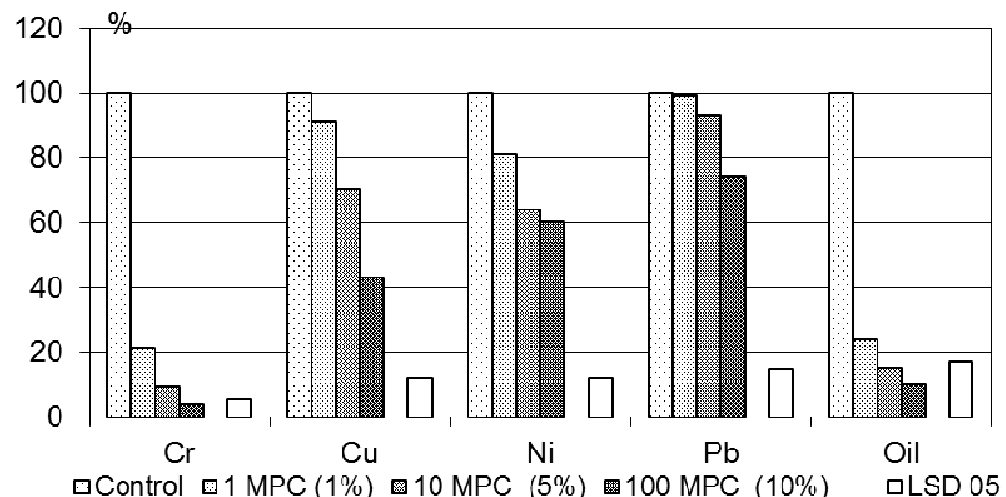

(C)

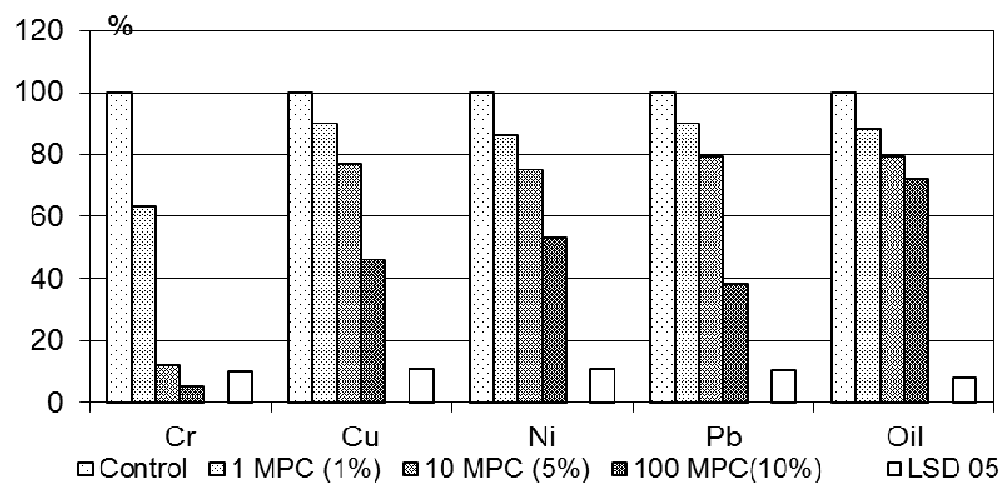

(D) 


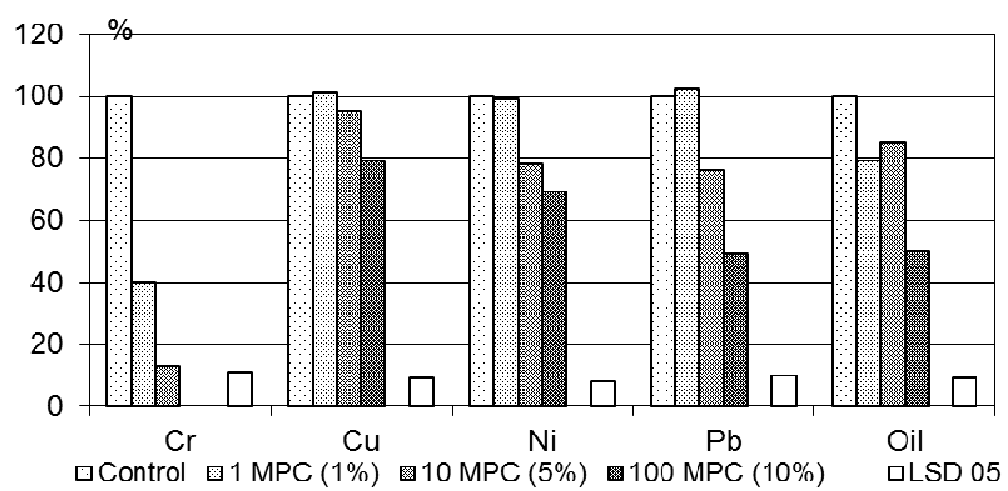

(E)

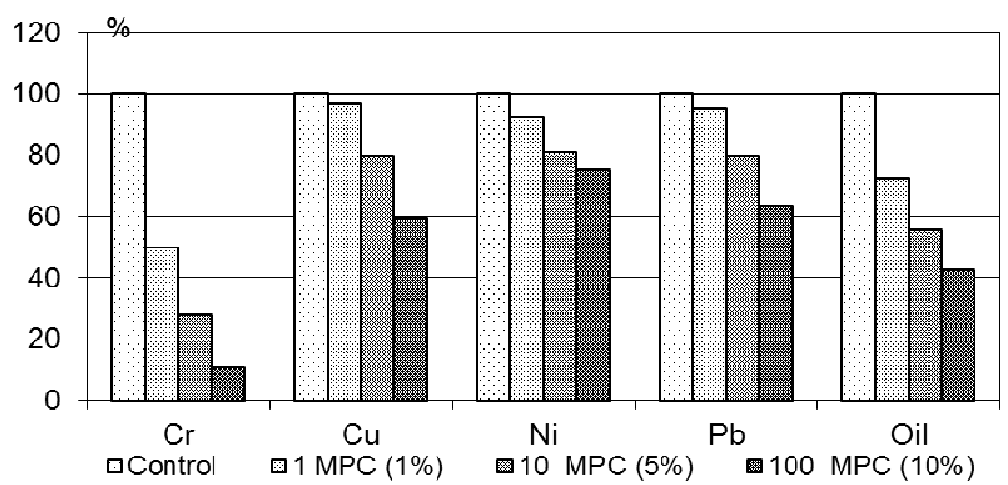

(F)

Fig. 1. The effect of chemical pollution of brown soil on biological properties of the soil (\% of control): (A) catalase activity; (B) dehydrogenase activity; (C) cellulolytic activity; (D) an abundance of Azotobacter genus bacteria; (E) the length of radish roots; (F) IPBS. (MPC-for HM, \%-for oil)

Accordingly, the series of heavy metals according to their degree of negative impact on the brown soil is as follows: $\mathrm{Cr}>\mathrm{Cu}>=\mathrm{Pb}>=\mathrm{Ni}$.

A similar pattern was obtained in earlier studies conducted in the same manner, with other soils in Southern Russia: Chernozem, brown, brown semidesert, gray and brown forest, calcareous, sandy and others. Chrome, regardless of the soil type always has a stronger negative impact than copper, lead and nickel. But the last three items, showing in general a similar degree of toxicity, on different soils occupy different places in a series of toxicity relative to each other (Kolesnikov et al., 2009; 2011; Kolesnikov et al., 2010a; 2013a; 2014a).

However, this sequence of HM according to their environmental hazard for soil does not always coincide with the previously obtained data on other types of the soil (GOST 17.4.1.02-83, 1983; Crommentuijn et al., 1997; Van de Plassche and De Bruijn, 1992). Possibly, higher chrome toxicity in chernozems is connected with the fact that chrome is more mobile in more alkaline and oxidizing conditions (Zachara et al., 1989) and low toxicity of lead is related to a high content of chernozem humic acids which bind lead stronger than, for example, copper (Morin et al., 1999; Manceau et al.,
2002). However, this question requires further specialized studies.

The comparison between toxic effect of heavy metals and oil seems incorrect as it is not possible to compare their concentration in the soil correctly.

In most cases, all of the studied substances registered direct correlation between concentration of the pollutant in the soil and degree of reduction of biological indicators.

The causes of HM and oil negative impact on biological properties of soil are as follows.

HM bind to sulfhydryl groups of proteins, whereby on the one hand the synthesis of proteins is suppressed, including enzymes, on the other hand, the permeability of biological membranes is impaired. Both, ultimately, lead to metabolic disorders (Torshin et al., 1990).

The oil negative effect on the soil biological processes is explained by the soil particles being enveloped in petroleum hydrocarbons, by the content of heavy metals, aromatic hydrocarbons and particularly phenols in oil, by accumulation of hydrocarbon oxidation products such as hexadecyl alcohol, palmitic acid, benzoic acid and salicylic acid etc. in oil, by significant increase in the ratio C: $\mathrm{N}$ etc. (Kireyeva et al., 1998). 
According to the degree of resistance to chemical contamination brown soils occupy the following position in the South Russian soils (soils are ranked according to their resistance reduction): Ordinary chernozem $>$ typical chernozem, southern chernozem $>$ leached fusion chernozem, dark brown, chestnut soil $>$ brown carbonate, light brown, mountain-meadow (subalpine), gray mountain forest $>$ brown semidesert, brown mountain-forest, solonetses, salt marshes $>$ sandy soils (Kolesnikov et al., 2009; 2011; Kolesnikov et al., 2010b; 2013b; 2014b).

The established sequence is determined by ecological and genetic properties of the studied soils, primarily by grading, alkaline-acid and redox conditions, organic matter content and biological activity.

Brown soils have a relatively high buffer capacity for HM contamination, similarly to light brown soils. Despite low humus content $(1.2 \%)$, the studied brown soil had a fairly high $\mathrm{pH}$ (8.2), which facilitates stabilization of the studied HM in the soil, reducing their toxicity in relation to the biological properties of the soil.

"Medium" level of biological activity and conditioning of the studied brown soil determines the "Medium" level of resistance to oil pollution.

The study showed that the indicators of the soil biological condition used in the study can be recommended for use in order to monitor, diagnose and standardize the chemical contamination of brown soil.

The study (Kolesnikov et al., 2002a) showed that the violation of the soil ecological functions happens in a definite sequence. As the concentration of the chemical pollutant in the soil increases, the disruption of ecosystem functions happens in the following sequence: information $\rightarrow$ biochemical, physic-chemical, chemical and integral $\rightarrow$ physical (The classification of soil ecosystem functions is given by (Dobrovolsky and Nikitin, 1990)). The fact that different ecological functions of the soil are disturbed with different pollutant concentration in soil, may lay in the basis of the environmental regulation of soil pollution. The Integral
Parameter of Biological State (IPBS) is proposed to serve as a criterion of degree of soil ecological functions violation. It was found that if the values of IPBS decreased by less than $5 \%$, the soil fulfills its ecological functions normally, with a decrease in the values of IPBS by $5-10 \%$ a violation of information ecofunctions takes place, by 10-25\% -biochemical, physico-chemical, chemical and integral, by more than 25\% -physical (Kolesnikov et al., 2002b).

In our view, the soil resistance to contamination or other human impacts must be understood primarily by resistance of integral biogeocenotic functions, such as the accumulation and transformation of matter and energy in biogeocenosis, sanitary function, the function of the buffer and the protective biogeocenotic screen, conditions for the existence and evolution of the organisms. Violation of this group of functions should be considered as the resistance threshold of the soil to human impact crossing of which is fraught with environmental crisis or even ecosystem catastrophe.

According to the results of the present study regression equations were determined reflecting the dependence of the decrease in IPBS values on pollutant content in soil. According to these equations pollutants concentrations were calculated at which there is a violation of certain groups of the soil ecological functions (Table 2).

The proposed approach and the quantitative values of pollutants in the soil, causing a violation of the ecological functions of different groups are appropriate to use in environmental regulation, where the main objective should be maintaining ecological functions of the soil.

The proposed approach and the developed method can be used in relation to other human impacts on the soil: Plowing, water logging, salinity, water erosion, deflation, etc. They can also be extended to terrestrial ecosystems as a whole, because the soil in the terrestrial ecosystem is a major component, depositing and transforming contaminants.

Table 2. Scheme of environmental regulation of brown soils of Ciscaucasia dry subtropics with heavy metals and oil according to the degree of ecofunctions violation

\begin{tabular}{|c|c|c|c|c|}
\hline Soils & $\begin{array}{l}\text { Not } \\
\text { contaminated }\end{array}$ & $\begin{array}{l}\text { Weakly } \\
\text { contaminated }\end{array}$ & $\begin{array}{l}\text { Medium- } \\
\text { contaminated }\end{array}$ & $\begin{array}{l}\text { Heavily } \\
\text { contaminated }\end{array}$ \\
\hline $\begin{array}{l}\text { Degree of reduction } \\
\text { of integral value }^{1}\end{array}$ & $<5 \%$ & $5-10 \%$ & $10-25 \%$ & $>25 \%$ \\
\hline $\begin{array}{l}\text { Violated ecological } \\
\text { functions }^{2}\end{array}$ & - & Information & $\begin{array}{l}\text { Chemical, physic-chemical, } \\
\text { biochemical, integral }\end{array}$ & Physical \\
\hline Element & \multicolumn{4}{|c|}{ Heavy metal content in soil, $\mathrm{mg} / \mathrm{kg}$} \\
\hline $\mathrm{Cr}$ & $<90$ & $90-110$ & $110-140$ & $>140$ \\
\hline $\mathrm{Cu}, \mathrm{Ni}, \mathrm{Pb}$ & $<50$ & $50-100$ & $100-250$ & $>250$ \\
\hline Pollutant & Oil content in & & & \\
\hline Oil & $<0,10$ & $0,10-0,15$ & $0,15-0,80$ & $>0,80$ \\
\hline
\end{tabular}

1. Definition of the integral parameter by (Kolesnikov et al., 2006).

2. Classification of ecological functions by (Dobrovolsky and Nikitin, 1990). 
The developed method for assessing the environmental impacts of soil degradation on the basis of its ecological functions violation can be used to conduct a variety of scientific and environmental activities: The Environmental Impact Assesment (EIA development); in bioindication and biodiagnostics of degradative changes in the soil; when biomonitoring soil condition, as well as natural and anthropogenically disturbed ecosystems in general; with ecological regulation of soil contamination and other degradation processes, the development of regional MPCs or APC; in determining the extent of liability (amount of fine etc.) for companies with poor environmental management; in developing methods for rehabilitation (recovery) of contaminated soils; in determining the maximum permissible anthropogenic load on the territory; when creating environmental maps (zoning, factual and probable); in predicting the environmental impact of economic activity on the territory; when assessing the risk of disasters; in the environmental assessment, certification, certification of the economic territory or entity, etc.

\section{Conclusion}

Contamination of brown calcareous soils with $\mathrm{Cr}, \mathrm{Cu}$, $\mathrm{Ni}, \mathrm{Pb}$ and oil leads to deterioration of their biological properties. There is a reduction in activity of catalase and dehydrogenase, an abundance of Azotobacter genus bacteria, cellulolytic activity and the length of radish roots. As a rule, there is a direct relationship between the content of contaminant in the soil and degree of deterioration of biological properties of the soil.

According to the degree of negative impact on the biological properties of brown soil $\mathrm{HM}$ form the following series: $\mathrm{Cr}>\mathrm{Cu}>=\mathrm{Pb}>=\mathrm{Ni}$. The pattern that chromium is more toxic and copper, lead and nickel have less and similar to each other degree of toxicity was established earlier in research conducted by the same method, with other soils in southern Russia.

According to the degree of resistance to heavy metals and oil contamination brown soils are closer to the brown chestnut soils, are less stable than chernozem and more stable than brown semidesert soils. This is determined by their ecological and genetic properties, primarily by grading, alkaline-acid and redox conditions, organic matter content and biological activity.

Regional standards of $\mathrm{Cr}, \mathrm{Cu}, \mathrm{Ni}, \mathrm{Pb}$ and oil content in brown soils of Ciscaucasia dry subtropics Ciscaucasia are proposed.

\section{Acknowledgment}

Investigation was supported by the Ministry of Education and Science of the Russian Federation $(6.345 .2014 / \mathrm{K})$ and by the Leading Scientific Schools program (NSh-9072.2016.11).

\section{Author's Contributions}

Sergey Ilyich Kolesnikov: Designed the research plan and organized the study and contributed to the writing of the manuscript.

Natalya Aleksandrovna Petrova and Natalya Aleksandrovna Vernigorova: Carried out the data collecting and analysis.

Kamil Shagidullovich Kazeev, Tatyana Mikhaelovna Minkina and Svetlana Nikolaevna Sushkova: Participated in giving advice and comments on the manuscript.

Yuliya Viktorovna Akimenko: Helped in coordination, drafting, editing of the manuscript and conducted the correspondence of the submitted paper.

\section{Ethics}

The authors declare no conflicts of interest and that this article conforms to the ethical standards specified by the American Journal of Agricultural and Biological Sciences.

\section{References}

Chakraborty, S., T. Bhattacharya, G. Singh and J.P. Maity, 2014. Benthic macroalgae as biological indicators of heavy metal pollution in the marine environments: A biomonitoring approach for pollution assessment. Ecotoxicol. Environ. Safety, 100: 61-68. DOI: 10.1016/j.ecoenv.2013.12.003

Crommentuijn, T., M.D. Polder and E.J. Van de Plassche, 1997. Maximum permissible concentrations and negligible concentrations for metals, taking background concentrations into account. RIVM Report 601501001. Bilthoven, Netherlands.

Dobrovolsky, G.V. and E.D. Nikitin, 1990. Functions of soils in biosphere and ecosystems (ecological importance of soil). M.: Science.

Dyachenko, V.V., 2004. Geochemistry, Taxonomy and Assessment of Landscapes of the North Caucasus. 1st Edn., Publishing Center "Complex", Rostov-onDon, pp: 268.

Gebrekidan, A., Y. Weldegebriel, A. Hadera and B. Van der Bruggen, 2013. Toxicological assessment of heavy metals accumulated in vegetables and fruits grown in Ginfel river near Sheba Tannery, Tigray, Northern Ethiopia. Ecotoxicol. Environ. Safety, 95: 171-178. DOI: 10.1016/j.ecoenv.2013.05.035

GOST 17.4.1.02-83, 1983. Nature protection, soil, classification of chemical substances for contamination control. GOST.

Kabata-Pendias, A. and H. Pendias, 1989. Microelements in soils and plants.

Kasyanenko, A.A., 1992. Quality Control of Environment. 1st Edn., RUDN Publishing, pp: 136. 
Kazeev, K.S. and S.I. Kolesnikov, 2012. Soil Biodiagnostics: Methodology and Research Methods. 1st Edn., Southern Federal University Publishing, Rostov-on-Don, pp: 260.

Kazeev, K.S., V.F. Valkov and S.I. Kolesnikov, 2010. Atlas of Soils in Southern Russia. 1st Edn., "Everest" Publishing, Rostov-on-Don, pp: 128.

Kireyeva, N.A., E.I. Novoselov and F.H. Kazeev, 1998. Carbohydrase activity in oil-contaminated soils. Eurasian Soil Sci., 31: 1444-1448.

Kolesnikov, S.I., N.A. Spivakova, L.S. Vezdeneeva, Y.S. Kuznetsova and K.S. Kazeev, 2013a. Influences of model pollution by oil on biological properties of soils of dry steppes and semi-deserts of the South of Russia. Arid Ecosyst., 9: 70-76.

Kolesnikov, S.I., N.A. Spivakov, L.S. Vezdeneeva, Y.S. Kuznetsova and K.S. Kazeev, 2013b. Impact of model oil pollution on the biological properties of soil of dry steppes and semi-deserts of southern Russia. Arid Ecosyst., 19: 70-76.

Kolesnikov, S.I., D.K. Aznaurian, K.S. Kazeev and V.F. Val'kov, 2010a. Biological properties of south Russian soils: Tolerance to oil pollution. Russ. J. Ecol., 5: 398-404.

DOI: $10.1134 / \mathrm{S} 1067413610050061$

Kolesnikov, S.I., D.K. Aznauryan, K.S. Kazeev and V.F. Valkov, 2010b. Resistance of the biological properties of soils in Southern Russia to oil pollution. Ecology, 5: 357-364.

Kolesnikov, S.I., K.S. Kazeev, R.K. Tatlok, Z.R. Tlehas and T.V. Denisova et al., 2014a. Biodiagnostics of Western Caucasus brown forest soils resistance to contamination with heavy metals, oil and oil products. Siberian J. Ecol., 3: 493-500.

Kolesnikov, S.I., K.S. Kazeev, R.K. Tatlok, Z.R. Tlekhas and T.V. Denisova et al., 2014b. Biodiagnostics of brown forest soils' resistance to oil pollution and heavy metals pollution in western Caucasus. Sibirskiy Ecologicheskiy Zhyrnal, 3: 493-500.

Kolesnikov, S.I., K.S. Kazeev and V.F. Valkov, 2002a. Ecological functions of soils and effect of heavy metal contamination to them. Soil Sci., 12: 1509-1514.

Kolesnikov, S.I., K.S. Kazeev and V.F. Val'kov, 2002b. Ecological functions of soils and the effect of contamination with heavy metals. Eurasian Soil Sci., 12: $1335-1340$.

Kolesnikov, S.I., K.S. Kazeev and V.F. Valkov, 2006. Ecological condition and function of the soil under the conditions of chemical pollution. Rostov-on-Don Rostizdat Publ.
Kolesnikov S.I., A.V. Evreinova, K.Sh. Kazeev and V.F. Val'kov, 2009. Changes in the ecological and biological properties of ordinary chernozems polluted by heavy metals of the second hazard class (Mo, Co, Cr and Ni). Eurasian Soil Sci. Eurasian Soil Sci., 8: 936-942.

Kolesnikov S.I., N.A. Spivakova and K.Sh. Kazeev, 2011. The effect of model soil contamination with $\mathrm{Cr}, \mathrm{Cu}, \mathrm{Ni}$ and $\mathrm{Pb}$ on the biological properties of soils in the dry steppe and semidesert regions of southern Russia. Eurasian Soil Sci., 9: 1001-1007.

Matveev, Y.M., I.V. Popova and O.V. Chernova, 2001. Reglamentacia I normirovanie sodergania chimicheskich soedinenii $\mathrm{v}$ pochvach (koncepcia I metodologia ustanovlenia predelno-dopustimich koncentracii)/Protection of surrounding environment. Soils.

MSU, 1991. Methods of soil microbiology and biochemistry. Under the editorship of D.G. Zvyagintsev, MSU.

Morin, G., J.D. Ostergren, F. Juillot, P. Ildefonse and G. Calas et al., 1999. XAFS determination of the chemical form of lead in smelter-contaminated soils and mine tailings; importance of adsorption processes. Am. Mineral., 84: 420-434. DOI: 10.2138/am-1999-0327

Manceau, A., M.A. Marcus and N. Tamura, 2002. Quantitative speciation of heavy metals in soils and sediments by synchrotron X-ray techniques. Rev. Mineral. Geochem., 49: 341-428. DOI: $10.2138 /$ gsrmg.49.1.341

Sheudzhen, A.H., 2003. Biogeochemistry. GURIPP "Adygea", Maikop, pp: 1028.

Torshin, S.P., T.M. Udelnova and B.A. Yagodyn, 1990. Microelements, ecology and human health. Success Modern Biol., 109: 279-292.

Valkov, V.F., K.S. Kazeev and S.I. Kolesnikov, 2008. Soils of Southern Russia. 1st Edn., "Everest" Publishing, Rostov-on-Don, pp: 320.

Van de Plassche, E.J. and J.H.M. De Bruijn, 1992. Towards integrated environmental quality objectives for surface water, sediments and soil for nine metals. RIVM Report 679101005. Bilthoven, Netherlands.

Zachara, J.M., C.C. Ainsworth, C.E. Cowan and C.T. Resch, 1989. Adsorbtion of chromate by subsurfase soil horizons. Soil Sci. Soc. Am. J., 53: 418-428. 